\title{
低温物質の熱物性（I ）
}

（低温環境における低温物質熱物性の基本的特徴）

\author{
稲葉英男 \\ 岡山大学工学部機械工学科 \\ 干700 岡山市津島中 $3-1-1$
}

\begin{abstract}
本解説は，低温環境状態（常温以下 $-80^{\circ} \mathrm{C}$ 位までの温度範囲）における物質の熱物性お よび伝熱機構の特徴を具体例を用いて（Ｉ）および（II）の２回に分けて紹介するものである. 低温状態における熱物性值としては，熱伝導率，此熱，温度伝導率，熱膨張率を取り上げ， それらの熱物性值が, 対象物質の組成, 構造および含有する水の状態により, 様々に変化 する様子を従来の研究成果に基づいて述べてある。さらに，低温環境状態における物質の 熱物性值の測定方法に関する問題点とその改善法についても言及してある.
\end{abstract}

\section{1。まえがき}

近年の技術革新の内で，低温に関係するものとして，低 温条件での超電導現象，流体の超流動現象，凍結保存によ る生体操作等が挙げられる，さらに，身近な日常生活に直 結した低温技術の利用は，低温食品，断熱材，蓄冷材，製 水, 土木, 建築, 冷凍空調等の工業界, そして農・林業, 水産業, 畜産業等の産業界において, 多数なされており, 我々の社会生活で欠くことの出来ない重要な技術の一つで ある。低温環境の発生法は, 融解, 蒸発, 昇華等の物理的 な自然現象による吸熱作用を利用した自然冷却（冷凍）に よるものと，機械的エネルギや熱エネルギで駆動する冷凍 機を利用した人工泠却（冷凍）によるものがある.

自然気候状態においては, シベリアにて最低気温 $-71.7^{\circ} \mathrm{C}$ の低温を記録したとの報告もあり，地球上の自然環境下で も, 人工的低温発生法であるドライアイスの昇華温度-78.5 ${ }^{\circ} \mathrm{C}$ 近くの低温状態が存在することに驚きを感じる次第であ る。一般に低温工業分野における低温の定義は，空気の液 化温度（液体窒素の沸点 $-196^{\circ} \mathrm{C}$ ）以下の低温状態とされて いるが，本解説での温度範囲は，我々の日常生活に身近な 低温環境として常温以下約 $-80^{\circ} \mathrm{C}$ 位までを対象とする。低温 物質の定義であるが，ここでは，常温下 $-80^{\circ} \mathrm{C}$ 位までの温度 環境下で，その物質の性質および機能を発揮できる物質と し，物質に含有する水分が常温下 $0^{\circ} \mathrm{C}$ 付近の未凍結の水の状 態と氷点下の氷の状態をも含むものとする。低温状態では, 水の状態そして物質自体でも，その熱物性は大きく変化す ることが知られている。

\section{2. 低温物質の熱物性と熱現象の定義}

ここでは，低温状態における物質の熱物性の種類とその 特異な伝熱現象について述べる。 （a）熱伝導率：熱伝導率 $\lambda[W /(m \cdot K)]$ は, 物質中を単位 面積・時間・温度勾配当たりに移動する熱流の割合と定義 され, 物質を構成する成分, そしてその構造配置に左右さ れる物性值である. 熱伝導率は, 熱移動のし易さ, すなわ ち一般には構成分子・原子の運動エネルギ（熱振動）の伝 達の容易さ（分子・原子量そして分子間距離）に依存する むのである，また，金属等は，物質尔子の熱振動以外に自 由電子も熱エネルギを運搬するために自由電子の動き易さ も，大きく熱伝導率に関係することになる，我々の使う物 質の多くは, 多成分そして異方性を有する不均質構造であ り, 各構成分子・原子の運動エネルギの伝達は, それらの 成分および構造による相互作用を受け, 複雑な様相を呈す ることになる、特に，自由電子を伴う金属類が混合された 物質においては, 自由電子の低温における振舞いが, 熱伝 導率に大きく影響する。それ故, 純金属, 合金, 非金属結 晶, 非定形物質, 液体, 気体の順に熱伝導率は小さくなる さらに，通常，物質は水分を含む場合が多く，この水分の 状態 (水蒸気, 水および水) そして水分の配置・形状によ り，低温物質の熱伝導率は，大きく影響を受けることにな る.これらのことより, 物質の熱伝導率は, 必ずしも温度 の降下と共に減少を示すものばかりでなく，逆に温度の低 下と共に増加するものもある。例えば，純銅，グラフアイ 卜，氷，凍結食品等，一般に多くの物質は，多成分そして 不均質構造を有することより，純粋な物質の熱伝導率と区 別して，見掛け上 (apparent)，又は有効 (effective)熱 伝導率と表現する場合もある。

（b）比熱：比熱 C $[\mathrm{kJ} /(\mathrm{kg} \cdot \mathrm{K})]$ は，単位質量当たりの物 質の温度を単位温度（1K）上げるのに要する熱量と定義さ れる。この場合の熱量は, 物質分子・原子の運動に基づく 固有のエネルギ量 [質量 $\times$ 速度の2乗］に関するもので，物 
質を構成する分子・原子の質量とその移動速度の関数とな り, 当然, 温度とも関係することになる. 従って, 物質を 構成する成分の種類および量的割合が明らかであれば，そ れらを積算することにより求めることが出来る加成性の法 則が一般に成り立つものである。また，当然のことながら， 物質が水分を含む場合には，水分の状態 (水蒸気，水，氷) に依存して，その比熱の值も変化することになる. 特に， 食品成分等に拘束される結合水等は，その比熱が自由水の 比熱と異なると言われ，その取り扱いが注目されるところ である. 従って, 凍結食品等においては, 自由水, 結合水 としての不凍水量が大きく比熱を左右するものとなる．般には, 温度の増加と共に, その物質の比熱は增加するこ とになる, 例外として, 水は, $30 \sim 60^{\circ} \mathrm{C}$ 位の範囲において その比熱は一度減少する傾向を示す. 通常の固体, 液体で は, 定圧比熱 $C_{p}$ と定容比熱 $C_{V}$ はほぼ同じであるが, 気体 の場合には大きく異なることより, 両比熱を区別する必要 がある、本解説においては，固体および液体の比熱を対象 とすることより，定圧比熱 $C_{\mathrm{p}}$ で議論を進める。

(c) 温度伝導率：温度伝導率 $\mathrm{a}=\lambda /\left(\rho \cdot \mathrm{C}_{\mathrm{p}}\right)\left[\mathrm{m}^{2} / \mathrm{s}\right]$ は， 熱伝導率, 比熱および密度の関数となり, 温度の伝幡速度 を表わす物性值である．ここで, 温度伝導率を構成する前 2者は，前述のように純物質を除けば，見脚け上の値となる． 一方, 密度は, 特に物質が気体を含む場合には, 蒿密度又 は見掛けの密度となり，その取扱いが面倒となる．従って， 単一な純物質以外では, その温度伝導率も見掛け上又は有 効温度伝導率と言うことになる。特に，含水物質で，氷点 下の条件での水分の状態 (水又は氷) により, その温度伝 導率も大きく変化することになる。

(d) 熱膨張率：熱膨張率は，熱エネルギにより物質を構成 する分子・原子の結合寸法の変化であり, 構成する各物質 の配列方向と結合力の強さにより, その熱膨張率は, 方向 性を持つものである. 特に, 固相, 液相そして気相へと水 等の物質の相変化に伴って, その熱膨張は大偪に変化し, 熱伝導率等の他の熱物性への影響を及ぼすものとなる。

（e）潜熱量：固-液間の潜熱量は, 当然のことながら, 温 度の降下に伴って, クラウジウスークラペイロンの法則か らも減少することとなる.また, 含水多孔物質および水溶 液等も不凍水の存在により, 見掛け上, その潜熱量は減少 することとなる。また，気一液間の蒸発潜熱量も温度の低下 と共に増加することとなるので, 低温気体では, 温度によ り潜熱量の評価を厳密に行う必要がある、蓄冷材等の水溶 液の固-液潜熱量は, 水溶液濃度と温度の関数となる。

これらの温度等に関係する熱物性以外に, 次で述べる低温 度領域の水の熱物理現象が低温物質の熱物性に関連する。

（a）過冷却：水が通常の水点下の温度条件でも氷へと相変 化しない不安定現象で, 氷核の発生と共に瞬時に氷相が形
成される。

（b）不凍水：高分子等の物質の表面に水が物質の分子間力 等により, 拘束そして結合されたりして，水のエネルギポ テンシャルの低下が見られ, 水と氷の両方の性質をもつ水 と定義される。

（c）氷点降下：水と水溶性物質の濃度に依存して決まる水 点降下 (溶質 $1 モ ル$ 当たり $1.86^{\circ} \mathrm{C}$ 氷点降下) と圧力による 水の承点降下（100気压で約 $0.75^{\circ} \mathrm{C}$ 承点降下）がある.

（d）過熱度 : 水を放射熱工ネルギ等にて内部より融解させ た場合に, 水の温度が $0.3^{\circ} \mathrm{C}$ 位に達しても氷の融解が認めら れない特異な現象である.

このような低温に係る水および氷の特異現象が, 含水低 温物質の熱物性の評価を複雑なものとしている. 図1は, 水 と氷の熱伝導率 $\lambda$, 比熱 $C_{p}$ および温度伝導率 a の低温度 領域における温度依存性を示したものである [1] .

氷の熱伝導率 $\lambda_{1}$ は $0^{\circ} \mathrm{C}$ の水点付近で水の熱伝導率入为の約 4倍も高く, 温度の低下と共に，入!の増大する傾向が見ら れる. 亦は, 半導体と誘電体の性質を示し, 温度低下に伴 うフォノン (音響子) の減少により, 熱伝導率の増加をも たらすと説明されている. 逆に, 承の比熱 $\mathrm{C}_{\mathrm{F} 1}$ は, 水の比 熱 $C_{\rho}$ に比較し, 約 $1 / 2$ と小さな値になる. さらに, 水の温 度伝導率 $a_{1}$ は, 水の温度伝導率 $a_{w}$ に比較し, 約 $8 \sim 9$ 倍も 大きく, 亦層内での温度の伝幡速度は, 水層中よりもかな り速いことが理解できる。

これらの水と氷の熱物性の大きな差は, 低温物質内の水 分の状態に依存して, その熱物性値に大きな影響を及ほす ことを示唆しているものと言える。

\section{3. 低温物質の熱物性に関連する分野と研究発表}

従来より，冷凍食品および断熱材を始めとする建材等は， その熱物性值を得ることで, 投入エネルギ量の軽減そして 機能維持の効率化が図られてきた。表1は, 低温物質に関連 する技術分野での熱物性に係る事項を記載したものである。

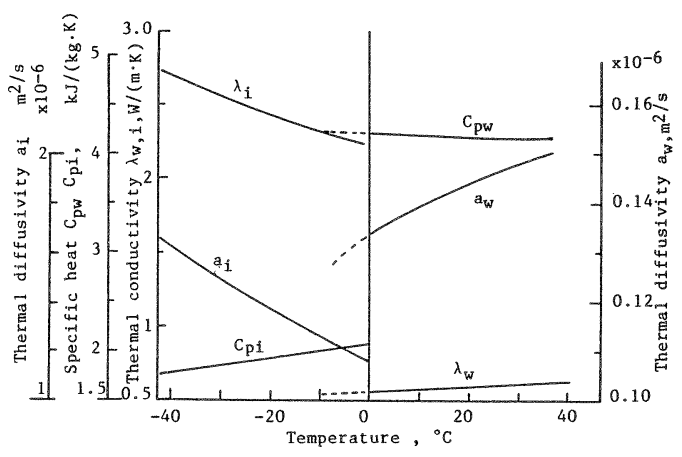

Fig. 1 Thermal properties of water and ice 


\section{表 1 各種技術分野と低温熱物性関連事項}

\begin{tabular}{|c|c|}
\hline 技術分野 & 低温熱物性関連事項 \\
\hline 農水産業，食品関係 & $\begin{array}{l}\text { 農水産物の貯蔵，輸送， } \\
\text { 食品加工・貯藏 }\end{array}$ \\
\hline 建築, 土木関係 & $\begin{array}{l}\text { 断熱材, 壁材, 床材, } \\
\text { コンクリート, 土畩等 } \\
\text { の熱・物質移動 }\end{array}$ \\
\hline 衣服,住環境,家政関係 & $\begin{array}{l}\text { 人間熱環境, 衣服の保温 } \\
\text { 通気性, 家電品の熱移動 }\end{array}$ \\
\hline 生体, 医用工学関係 & $\begin{array}{l}\text { 生体物質, 人工臟器, } \\
\text { 凍結保存, 低温手術 }\end{array}$ \\
\hline バイオ工学関係 & $\begin{array}{l}\text { 低温培養技術,植物工場， } \\
\text { 樹木の凍害 }\end{array}$ \\
\hline 冷凍，空調関係 & 代替冷媒,ブライン,霜,製圱 \\
\hline エネルギ関係 & $\begin{array}{l}\text { 蓄冷材, 寒绪, 自然冷熱 } \\
\text { エネルギ, 液化天然ガス } \\
\text { (LNG) の冷熱 }\end{array}$ \\
\hline 宇宙、航空関係 & $\begin{array}{l}\text { 材料の低温破壊, 極低温 } \\
\text { 断熱材，着办 }\end{array}$ \\
\hline
\end{tabular}

従来より低温物質に関して，体系的に綯て，出版物等に 公表されたものは非常に少ない現状にある。これは，低温 物質を総合的に扱う専門の学会等の組織が無く，低温と言 う特殊性のために，既存の学協会内で分散した形で，低温 物質の熱物性が扱われていることによるものと思われる。

次に, 日本熱物性学会関連の熱物性シンポジウムおよび 熱物性ハンドブックにおいて，低温物質の熱物性に係ると

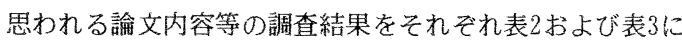
示す.

表2以外に，低温物質に関係したものとして，磁場中での 比熱測定法, レーザによる熱膨張率の測定法, 放射率の測 定法が各 1 件ずつ発表されている。これらを含めると総論文 903件中50件が低温物筫の熱物性に係るものである。

表2の低温物質の熱物性に関する発表論文が全体の発表件 数に比較して少ないのは, 当シンポジウムが広範囲な物質 の熱物性とその測定法を対象としていることによるものと 思われる.また，一般に低温に係る物筫の多くは，食品， 断熱材等に見られるように, 多成分, 異方性を有する不均 質材料が多く，低温物筫を構成する各成分単体の熱物性値， 各成分の配置構造そして構成割合等の幾何学的条件の複雑 さ, そして測定時の環境条件 (温度, 湿度) の規定が難し いことによる測定精度および物質状態の特定の困難さ等も， 発表件数の少なさに関連しているものと考えられる.
日本熱物性シンポジウム：第1回開催(1980年)～第13回 (1992年), 総論文数約 903 件

表 2

\begin{tabular}{|c|c|c|}
\hline 測定対象 & 測定熱物性 & 論文 \\
\hline $\begin{array}{l}\text { 建築材料（断 } \\
\text { 熱材,壁材） }\end{array}$ & 熱伝導率，比熱, 温度伝導率 & 8件 \\
\hline 凍土, 岩石 & $\begin{array}{l}\text { 熱伝導率, 比熱, 温度伝導率 } \\
\text { 熱膨張率 }\end{array}$ & 12件 \\
\hline $\begin{array}{c}\text { 食品 (農産物 } \\
\text { 水産物) }\end{array}$ & 熱伝導綷, 比熱, 温度伝導摔 & 8 件 \\
\hline $\begin{array}{l}\text { 生体（血液， } \\
\text { 角膜） }\end{array}$ & 熱伝導率, 温度伝導率 & 3件 \\
\hline 霜, 雪, 水 & 爇伝導率, 温度伝導率 & 6件 \\
\hline $\begin{array}{l}\text { 不凍液（エ爭 } \\
\text { ゲリエール水溶液 } \\
\text {,海水） }\end{array}$ & 熱伝導率, 過冷却度 & 5件 \\
\hline $\begin{array}{l}\text { 玲媒 } \\
\text { (フロン系) }\end{array}$ & 熱伝導率, 比熱, 温度伝導率 & 3件 \\
\hline $\begin{array}{l}\text { 蓄冷材 (パラ } \\
\text { フィン系) }\end{array}$ & 熱伝導率, 此熱, 潜熱 & 2件 \\
\hline
\end{tabular}

熱物性ハンドブック:1990年発行, 総章数 27

表 3

\begin{tabular}{|c|c|c|}
\hline 章名 & 対象分野 & 測定対象物質 \\
\hline $\mathrm{C11}$ & 低温および極低温 & $\begin{array}{l}\text { ブライン, 冷媒, 金属, } \\
\text { 非金属材料, 断熱材 }\end{array}$ \\
\hline $\mathrm{C} 12$ & 食品, 農産物 & $\begin{array}{l}\text { 穀物, 青果物, 食肉, } \\
\text { 加工食品 }\end{array}$ \\
\hline $\mathrm{C} 14$ & 環境·自然 & 雪, 氷, 海氷, 霜, 岩石, 凍土 \\
\hline $\mathrm{C} 15$ & 生体・バイ才,医学 & 血液, 各種生体組織, 器管 \\
\hline
\end{tabular}

4. 各種低温物質の熱物性の特色 前述のように, 日常生活に関係の深い低温物質は, 多成 分，異方性を持つ不均質混合物である場合が多い。さらに， 多くの低温物質は, 水分を含み, 水の状態そして挙動が, 低温物質の熱物性に大きな影響を及ぼすことになる。以下， 低温物望に係る各分野における水分の状態と熱物性の特幑 的な関係についての例を解説する。

4.1 食品の低温状態における熱物性

4.1.1 食品の熱物性に係る特色

食品原料の大部分は，農，林，水産物そして畜産物より 
構成されており，それら生物組織としての鮮度維持を主目 的として食品の流通, 貯蔵そして加工・調理のブロセスに 多大のエネルギを費やしている現状にある.特に, これら 各プロセスにおいて, 泠却, 凍結および解凍等の低温赺理 を行う上で, 被泠却・凍結食品の低温熱物性が, 各操作機 器の設計および伝熱解析に基づく投入エネルギの推定に必 要となる. 最近は, 単に食品の彾却, 凍結ばかりでなく, 凍結による乾燥, 濃繟粉砕又は磨砕等は, 高圧そして真空 状態と組合わせた新技術を発展させる上でも詳細な食品の 低温熱物性の把握が必要不可欠となっている。しかしなが ら, 食品は一般に不定形で多成分を含みかつ幾何学的に複 雑な組織を持つ不均質混合物の場合が多く,そして周囲条 件により容易に変成するものである。これらの食品の特幑 が原因となり, 統一的な食品物性の評価法, 適当な測定法 そして食品物性値の推算法の確立を困難としている.

食品中の水分は，食品の主要な成分となるばかりでなく， 熱物性を支配する重要な因子となる. 食品内水分の大部分 は, 細胞内のゲル状組織あるいは繊維状架橋構造を有する 巨大分子であるコロイド状複合体そして水和物の形で結合 水の状態で存在する。特に, 凍結の際には, 食品組織内の 自由水の凍結が兒られ, 自由水に溶けている各種溶質の沈 殿および結合水の不凍水化等水の状態の変化そして食品組 織の変性等がその熱物性に大きな影響を及ぼすことになる。 凍結による微生物の繁殖抑制作用, 酵素作用の制御等の長 所を利用し, 我の形成に伴う食品組織の破壊, 変性等の欠 点を最小限とする最適な伝熱操作を遂行する基礎となるの が，熱物性と言えよう。

\section{1.2 低温食品熱伝導率の特色}

食品成分は，主に固形分である蛋白筫（未凍結状態 $\left(2^{\circ} \mathrm{C}\right.$ ) 熱伝導率 $\lambda=0.30 \sim 0.34 \mathrm{~W} /(\mathrm{m} \cdot \mathrm{K})$, 凍結状態 $\left(-10^{\circ} \mathrm{C}\right) \lambda=0.49$ $\sim 0.58 \mathrm{~W} /(\mathrm{m} \cdot \mathrm{K})$ )，炭水化物（未凍結 $\lambda=0.20 \sim 0.24 \mathrm{~W} /(\mathrm{m} \cdot \mathrm{K})$ ， 凍結 $\lambda=0.21 \sim 0.40 \mathrm{~W} /(\mathrm{m} \cdot \mathrm{K}))$ および脂肪 $(\lambda=0.14 \sim 0.19 \mathrm{~W}$ $/($ m・K $)) ，$ 水分 (水の状態による熱伝導率は四1に示される) そして空気 $\left(\lambda=0.025 \mathrm{~W} /(\mathrm{m} \cdot \mathrm{K}), 0^{\circ} \mathrm{C}\right)$ より構成されている. 各成分は, 幾何学的に不均質な混合体として食品形状を形 成しており,さらに, 温度, 圧力等の条件により食品組織 の変性を伴う. 従って, 熱伝導率の測定に際しては, 迅速 かつ熱流方向を考慮した非定常測定法が有効な方法と思わ れる，当然のことながら, 純粋な単一成分よりなる物質の 熱伝導率とは異なり，不均質泚合体としての熱伝導率は， 伝熱機構を加味した有効又は見掛けの熱伝導率となる。

食品の熱伝導率の測定にあたっては, 測定用センサと対 象食品の寸法関係も大きな測定䛊差要因となる。図2は非定 常プローブ法にて，穀物の熱伝導率測定における最適プロ 一ブ直径Dと穀物の大きさ（水力直径 $\mathrm{d}_{\mathrm{E}}$ ) の関係 [2] を示
したもので，寸法比 $D / d_{\ominus}$ の值が1以上あれば定常平板加熱法 で測定した値と一致することがわかる．このように，不均 質混合体である食品の熱物性測定には，センサ寸法も大き な測定条件となる。

一般に, 食品は不均質構造を有しており, 特に果実や野 菜そして魚類等の生鮮食品は, 食品内部構造により組成も 異なり, 爇伝導率の局所值に大きな差を生じる. 特に, 果 実の表皮部は熱伝導率の小さな空気や炭酸ガスを多く含む ため, 果肉部の水分を多く含む部分との熱伝導率の差が大 きくなる.四3は，玉苟心芯，中央そして表皮部分の熱伝導 率を非定常細線法により測定した結果を示したものである

[3]. 含水率の大きな $\mathrm{X}=21 \mathrm{~mm}$ の中央部が含水率の小さな表 皮そして芯部より大きな熱伝導率を亦し, 特に, 凍結温度 領域においては，氷の熱伝導率が水のそれよりも約4㥉も大 きいことより，各部の熱伝導率に大きな差が見られるよう になる、逆に、食肉中の熱伝導率の小さな脂肪分の含有割合 が変化した場合の熱伝導率（肉絨維方向に垂直に熱流を与

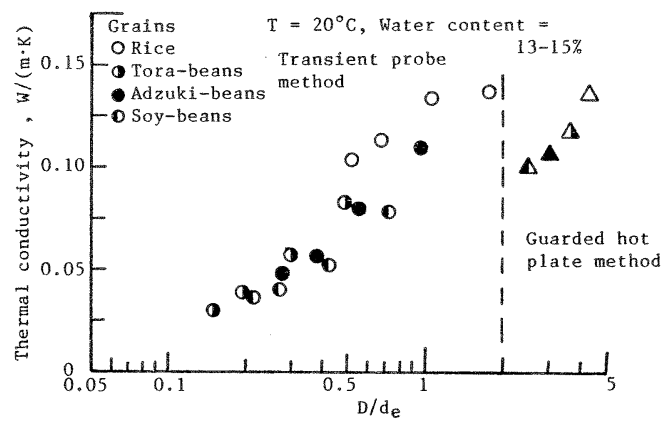

Fig.2 Thermal conductivity vs. diameter ratio of probe to grain

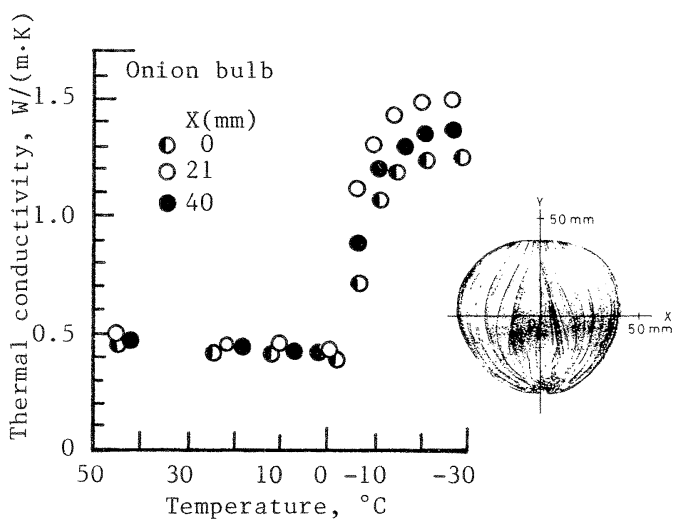

Fig. 3 Variation of thermal conductivity with temperature for onion bulb 
えた場合）と温度の関係を示したものが図4である [4]．

未凍結温度領域では，それほど脂肪分割合による熱伝導 率の差は少ないが, 凍結領域においては, 熱伝導率の小さ な脂肪分割合の増大と共に肉の熱伝導率の減少傾向が著し くなる傾向にある.食肉のように繊維質より構成されてい る食品は, 繊維方向における熱伝導率が, 瀻維方向に垂直 方向の熱伝導率よりも約20〜30\%大きいと言われている. また, 凍結速度の増大と共に微細な水結晶の形成が食品内 に見られ, 食品の熱伝導率の隇少となり, 凍結速度も冷凍 食品の熱伝導率に影響を及ぼすことになる。このように食 品の熱伝導率に影響を及ぼす諸因子には，構成成分の熱伝 導率, 成分割合, 各成分の幾何学的構造, 水分の状態等以 外に, 凍結の際の氷形成履歷等も重要な因子となる。従つ て, 食品の凍結領域を含む跾密な熱伝導率(見掛け上の熱 伝導率) 推定の数理モデルの難しさが同える. 最近, 高級 鮮魚等の部分凍結又は未凍結保存である氷温眝蔵の低温管 理においては, 特に, 部分凍結時の熱伝導率が, 凍結線予 想に重要な因子となる。

\subsection{3 低温食品比熱の特色}

一般に，食品比熱の多くは，水分，脂肪と固形分の含有 率と各成分比熱の積を累加することにより算出することが できる加成性を持つものである。しかしながら，食品の固 形分に水分が強く拘束される結合水割合の多い食品（コ口 イド状食品）等は, 自由水とは異なる結合水の比熱を考慮 しなければならない。図5は，小麦中の結合水を含む水分の 熱量と自由水の持つ熱量の差を,水の熱容量 $Q=C_{0} \cdot T[\mathrm{~kJ} / \mathrm{kg}]$ と温度 $\mathrm{T}\left[{ }^{\circ} \mathrm{C}\right]$ の関係で示したものである $[5]$. 承点以上の 温度条件では，小麦中の水分の持つ熱容量Qが温度上昇そし て含水割合の増大と共に, 自由水と比較して大きなものと なる。これは, 温度の上昇に伴い, 結合水割合を減少させ るためにより多くの熱量が必要となるものと判断される. 従って, 結合水の見掛け上の比熱は, 自由水の比熱よりも 大きいと結論付けられる。一方, 氷点下の温度域では, 小 麦の含水率の大きいもの程自由水含有割合も大きく, 形成 される氷の割合も增大することより，熱容量 $\mathrm{Q} の$ 值も純水の 比熱へ近づく傾向となる．食品等水分を多く含む物質が凍 結を伴う場合には，凍結による潜熱量を比熱に含めた見掛 けの比熱として扱うことがある。

図6は，小麦の見掛けの比熱と温度の関係を含水率 (w\%) をパラメータにとって示したものである [6]．含水率が $20 \%$ 以下では, 温度上昇に伴ってほぼ直線的に見掛けの比 熱の増加が見られ，このような含水率範囲では, 結合水の 凍結が認められないものと思われる.含水率が $20 \%$ 以上の 領域では，自由水の存在割合が大きくなり，氷形成に伴う 潜熱放出により見掛け上の比熱の増大する温度带が現われ

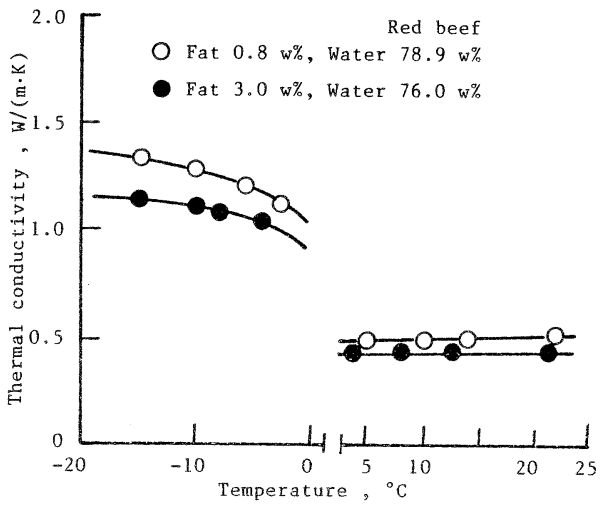

Fig. 4 Variation of thermal conductivity with temperature for red beef

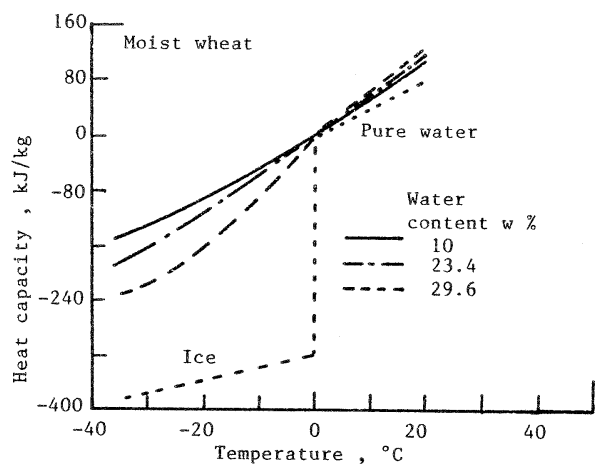

Fig. 5 Variation of heat capacity with temperature for moist wheat

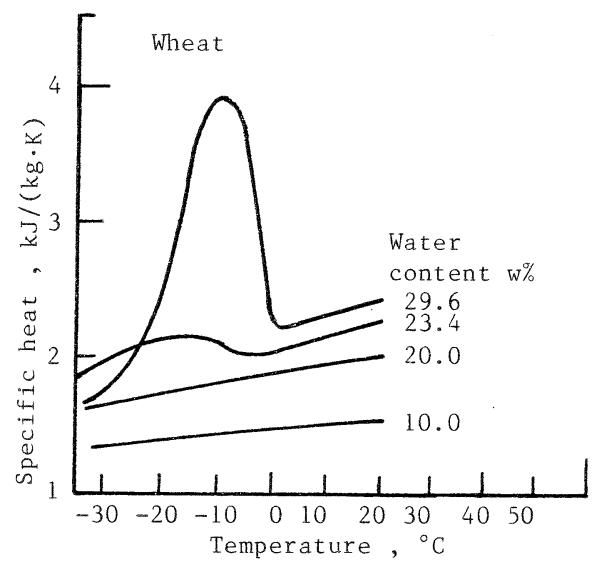

Fig. 6 Variation of specific heat with temperature for wheat 
る. 食品の凍結に伴う潜熱放出は, 自由水の凍結に伴う潜 熱集中型の潜熱放出とは異なり，様々な食品組織と結びつ いた結合水の結合力の差により, 凍結温度が異なることが 原因で，一㮔の潜熱分散型の特性を示すことになる。

前述の穀物の比熱とは異なり, 凍結牛肉の見掛け上の比

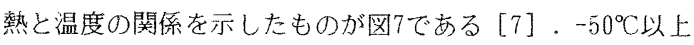
の温度領域では, 温度の降下と共に急激な比熱の低下が見 られる。これは, 温度の低下と共に不凍水の割合が減少し, 氷結量の減少（潜熱放出量の減少）が見掛けの比熱の減少 をもたらすものと思われる，さらに， $-50^{\circ} \mathrm{C}$ 以下の温度では， 氷結が進行しない状態又は完全凍結となり，比熱の加成性 に適合する温度領域となる。四中の破線は， $-50^{\circ} \mathrm{C}$ 以下の温 度領域の比熱より類推して引いた線で, 潜熱放出熱を差し 引いた真の比熱と言える。

\subsection{4 その他低温食品の熱物性に係る特色}

食品組織内の水は, 構成成分に拘束された結合水, 生体 高分子や溶質との水和水，各種溶質を含む水溶液の形で, 自由水と異なるエネルギ状態で存在し, 凍結しづらい水で ある、特に, 凍結食品の場合には, 食品中の水の状態およ び凍結速度が，氷の発生する凍結温度そして形成された氷 結晶の大きさを左右し，凍結食品の性状に大きな影響を及 ぼすことになる，その他に，凍結しづらい水には，過冷却 状態の水, 毛管作用を受ける水, 表面エネルギの大きい微 小水滴で存在するエマルジョン水等がある. 凍結食品内の 不凍水量の算定には, 熱量計法, 遠心分離法, 融解体積変 化法等が, 従来より用いられてきたが, 近年非接触で食品 組成を変化させることなく, 不凍水分量の推定方法が開発 されている。その一つは, NMR (核磁気共鳴) 法で, 不凍水 のプロトン分子運動性が承晶状態よりもかなり大きいこと

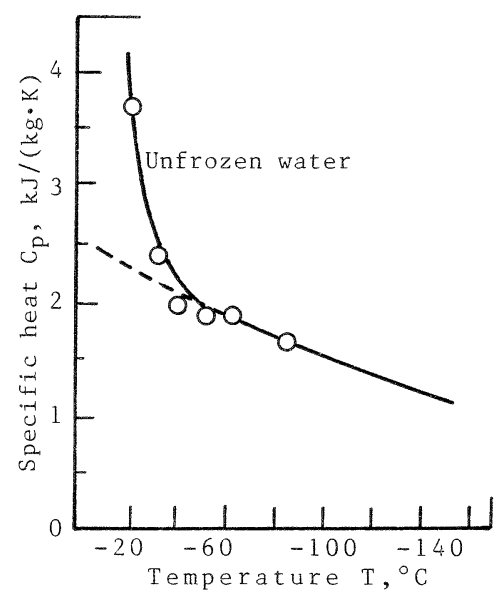

Fig. 7 Specific heat of frozen beef
に着目し，パルスNMRで観測される自由磁気誘導隇衰割合の 変化で, 凍結食品の凍結水量を求めるものである.NMR法で, 様々なゲル状食品の凍結発生温度そして凍結量が測定され ている。

一方, 超音波法は, 超音波の速度が水分量に対して凍結 層で2〜3倍に増加する現象を有し，それに伴って，超音波 の入射エネルギの大部分が，凍結界面で反射され，凍結物 質中の凍結層の割合が，非接触で測定できる [8]．この方 法は, 臓器等の凍結保存による凍結界面そして凍結量の予 想に関する臨床実験に利用され, 今後, 一般の凍結食品の 凍結量の測定に利用されるものと思われる。

以下，低温食品における凍結現象と熱物性に係る例を列 記する

（a）凍結に伴って形成される氷結晶が食品細胞組織を破壊 する場合があるため，低泠却速度のもとで食品組織内水を $-5^{\circ} \mathrm{C}$ 程度まで過冷却状態を維持し, その後 $-5^{\circ} \mathrm{C}$ 以下に急速 凍結させると食品内に笑然微細な水結が形成される(フラ ッシング現象）。フラッシング現象を利用することにより， 安定な凍結食品ができる. 各食品原料の水溶液を過冷却限 界そしてフラッシング現象を起こさせるための熱移動を特 定できる熱物性デー夕が重要な技術的要素となる。

（b）他に過冷却現象を利用したものに，アイスクリームの フリージング操作がある.アイスクリーム原料と空気を混 合 (オーバーラン) させながら冷却すると, 含有される微 小水滴の過冷却状態より，急激に微細な承結晶が形成され る。過冷却度が大きければ大きい程办結晶が稠密となり, 良質のアイスクリームとなると言われている。この場合に は, 熱伝導率の小さな空気泡を含有したアイスクリーム原 料の熱物性が, その凍結速度に関係することになる。

（c）食品の凍結濃縮においては，溶液中に懸濁する様々な 粒径分布を持つ承結晶を熟成槽内で, 分離の容易な大粒径 氷結晶に成長させる.この場合, 各溶液濃度の水点付近の 熱物性データが, 氷結晶熟成予想のために重要な因子となる. (d)さらに, 最近においては, 加圧による凍結温度の降下， 加圧解凍そして隇圧凍結等の低温圧力操作により, 食品の 基本的成分および構造の変化を伴うこと無しに, 凍結・解 凍を行う技術が活用されている $[9]$ 。この場合には, 食品 の圧力変化に伴う熱物性の評価が，加圧操作条件を決める 大きな要因となる。

（e）凍結乾燥過程においては，図8に示すように，凍結層を 減圧下での昇華蒸発により乾燥させるもので, 凍結界面へ の熱供給(放射熱, マイク口波の利用)は, 固形分と空気層 よりなる乾燥層を通じて行う，従って，乾燥層での放射熱， マイク口波の透過性そして兒掛けの熱伝導率と発生した水 蒸気の拡散速度が涷結乾燥の効率に大きく影響する [10］。 （f）低温食品の熱膨張率に関係するものに, 凍結魚体表面 


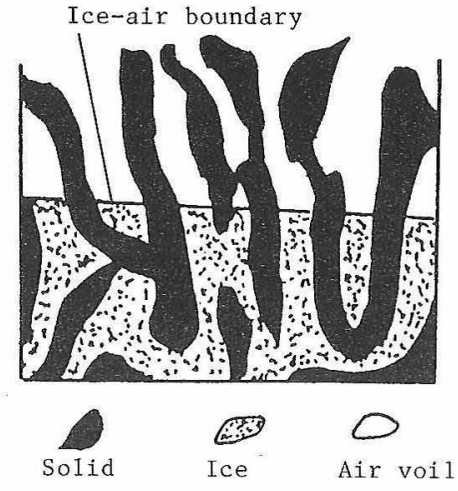

Fig. 8 Freeze-dry model

の身割れ現象や食品の凍結粉砕等がある．これらは，低温 における食品の熱膨張率と氷量変化の相乗効果による内部 応力の増大に伴って起こるものであり，食品の温度と熱膨 張率の関係を明らかにし，身割れの防止そして谏結粉砕の 効率化を図る必要がある。

4. 2 農業, 林業, 水産業産物における低温熱物性の特色 4. 2.1 樹木の凍裂

凍裂とは，図9(a),(b)に示されるように樹幹が著しい低 温のために縦裂する現象であり，晚冬から早春にかけての 樹液が循環を始めた時期に，急激な温度の低下を生じた場 合に発生し易い [10] . 凍裂の発生の時間帯は, 深夜から 日の出までの最低気温記録時に起こるもので，凍裂の際に， 強く音響を発生する，凍裂の機構は，未だ十分に解明され てはいないが, 次のように説明される.

樹木の熱収縮が起こり，内圧が上界した状熊となる。一 方, 樹木内の水分は, 泠却と共に過泠却状態となり, エネ ルギポテンシャル的にある過冷却温度以下になると氷核の 形成が起こり，急激に樹木内に氷量の増大を生み，結果と して, 冷却による樹木収縮力よりも承形成に伴う圧力上昇 が上まわった状態で，凍裂が発生するものと思われる．特 に，樹木の中でも含水割合の多い水食い材は地上 $1 \sim 2 m$ の高 さでの谏裂発生が多く，水分割合と過冷却度に関係した生 成氷量が大きな凍裂因子となる，当然のことながら，凍裂 の予想には，樹木の芫掛けの熱伝導率および熱膨張率の熱 物性データが欠かせないものとなる。

\section{2.2 養殖業における給䬣および増殖子の凍結保存 における低温物性}

養殖ハマチ等の大型魚の慨には，小型の多獲性魚および 配合飼料が用いられているが，環境への残饂の昿散による
自家污染防止そして給餌労力の軽減の立場より, 凍結状態 の䬣を配管を通じて解凍せずに給餌する方法が採用され始 めた [11] .この場合, 養殖場の水温, 凍結割合（硬さ）, 凍結慨の大きさそして凍結慨の熱伝導率がその融解速度に 大きく影響することになる. 従って, 凍結䬧の解凍尒想に は，水と各種慨飼料の湜合した見掛けの熱伝導率デー夕が 重要となる。

一方, 人工養殖で問題となる雌および雄魚の成熟に差が あるような魚種そして絶隇の危機に直面している希少魚に 対しては, 精液等の凍結保存が時間的, 空間的ギャップを 埋める適切な手段として活用されている, 凍結保存条件維 持そして解凍条件確立のためには，その温度管理が重要な 因子となり，凍結緩和剂を含んだ涷結精液等の見掛けの熱 伝埒率および熱容量情報が不可欠となるが，末だそれら熱 物性データの報告は少ないようである。

\section{2,3 農産物の呼吸, 腐敗そして水和熱による 熱物性への影響}

貯蔵状態における農産物は, 呼吸, 腐敗そして水和作用 による発熱特性を特ち, これらの発生熱量の低温依存性を 知ることが，冷却負荷決定に必要となる．特に，水分㫪と 呼吸熱の関係が，冷却負荷に大きく影響を及ぼすことにな る. 縠物や野菜等の農産物の熱伝導率や比熱測定の際には， 農産物の呼吸熱そして水和熱等の発熱量を含んだ状態での 測定値となり，測定された熱物性値は，発熱を伴わない場 合よりも大きくなるので, 補正が必要となる。例えば，10 ${ }^{\circ} \mathrm{C}$ 前後の低温下で野菜葉の熱伝導率を非定常ブローブ法で 測定する際のプローブ発熱量に対して，5〜10\%に相当する 呼吸熱の発生があると言われている.さらに，水和熱の発 生でも，低水分小麦で1週間位そして $16 \%$ 以上含水率の小 麦で3週間位もの間発熱が持続するとの報告もある [12]．

その他の各種低温物質の熱物性の特色は，低温物質の熱 物性（II）（具体的な低温物筫熱物性の特徴）で解説を行う.

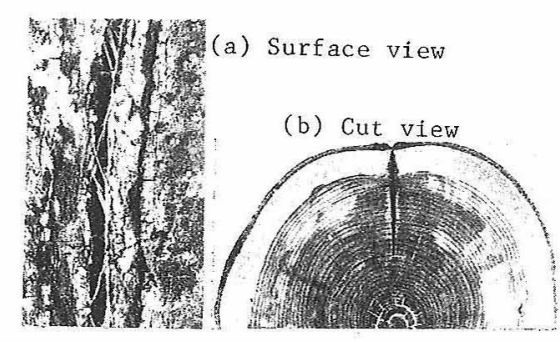

Fig.9 View of Tree trunk crack by freezing 
参考文献

[1]日本機械学会, 伝熱工学資料 (改訂第3版) 298 頁 (日本機械学会, 1975).

[2] H. Inaba, Int.J.of Thermophysics,7(1986)773.

[3] 稲葉英男, 第4回日本伝熱シンポジウム講演論文集, 4(1983)17.

[4] J.E.Hill, Food Technology, 21(1967)1143.

[5] W.E.Muir, S.Viravanichai, J.Agric.Engng. Res., $17(1972) 338$.

[6]稲葉英男（分担），関信弘（代表），新材料・新作動 流体の熱物性値の研究促進, 21頁(昭和60年科研総合 研究報告書, 1986)

[7] 日本熱物性学会, 熱物性ハンドブック，446頁（日本 熱物性学会, 1991)

[8] B. Rubinsky, 青井秀雄（訳），给凍，67(1992)1304.

[9]蒔田董, 他3名, 冷凍, 66(1991) 930 。

[10]稲葉英男, 福迫尚一郎, 機械の研究, 43(1991)1138.

[11] 黑倉寿, 冷凍, 66(1991)916.

[12] N.N.Mohsenin，林弘通（訳），食品の熱物性，267頁 (光琳，1985）.
Thermophysical Properties of Cold Substances (I )

(Fundamental Characteristics of Thermal Properties in Cold Environments)

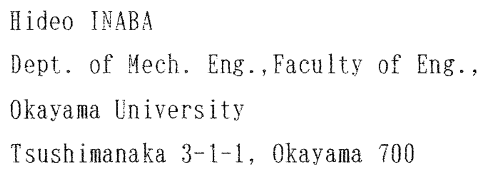

This review paper deals with thermophysical properties and heat transfer phenomena of the substances in cold temperature environments. Thermal conductivity, specific heat, thermal diffusivity and thermal expansion coefficient as thermal properties and supercooling water, freezing point regression etc. as heat transfer phenomena are discussed about low temperature substances on the strength of previous works. Moreover, measuring methods of thermophysical properties under the cold temperature condition are also observed in the present review.

(Received Feb. 8, 1993) 